\title{
Robson ten groups classification system for caesarean section audit: are our operation theatre registers RTGC enabled?
}

\author{
Fasiha T. Abdul Aziz ${ }^{1 *}$, Sushma R. Bhoosreddy ${ }^{2}$
}

\begin{abstract}
${ }^{1}$ Department of Obstetrics and Gynecology, Dr. Shankarrao Chavan Government Medical College, Vishnupuri, Nanded, Maharashtra, India

${ }^{2}$ Department of Obstetrics and Gynecology, Rajiv Gandhi Institute of Medical Sciences, Adilabad, Telangana, India
\end{abstract}

Received: 28 June 2019

Accepted: 14 August 2019

*Correspondence:

Dr. Fasiha T. Abdul Aziz,

E-mail: fasiha.aziz@yahoo.com

Copyright: (c) the author(s), publisher and licensee Medip Academy. This is an open-access article distributed under the terms of the Creative Commons Attribution Non-Commercial License, which permits unrestricted non-commercial use, distribution, and reproduction in any medium, provided the original work is properly cited.

\section{ABSTRACT}

Background: Rising caesarean section rate is a global problem. Robson ten groups classification (RTGC) system of audit has been recommended as the first step towards planning strategies to reduce caesarean section rate. Getting data for this audit is often difficult. If operation theatre (OT) registers are maintained properly this would become easy. The study proposes to know if enough information is available in the operation theatre registers to get caesarean section data for ten groups of Robson classification system. To suggest changes in OT register format for future convenience.

Methods: We studied data from 100 consecutive caesarean section entries in OT registers from two medical college institutions to know if the information recorded is adequate to classify these 100 caesarean sections into ten groups given by Robson. Last 100 caesarean section entries into the OT register during the period $1^{\text {st }}$ April 2018 till $31^{\text {st }}$ March 2019 were studied.

Results: Presentation of the foetus was the only factor which could be clearly known for all 100 cases. Labour onset whether spontaneous or induced was the least recorded observation in traditional operation theatre registers. The next information which was commonly not recorded was the labour status (woman in labour or not in labour) at the time of caesarean section.

Conclusions: For Robson's classification of caesarean sections to become useful tool to guide strategies in reducing caesarean sections we need to modify format of our OT registers. Traditional OT registers do not provide enough information to categorize caesarean section cases into Robson ten groups. Missing information makes caesarean section audit imperfect or impossible. We suggest a format for it to be incorporated into the operation theatre registers of centres providing maternity services.

Keywords: Caesarean section audit, Operation theatre register, Robson ten group classification system, RTGC

\section{INTRODUCTION}

Rising caesarean section rate is a matter of global concern because of its associated health and economic consequences to the individuals, to the societies and to the governments. ${ }^{1,2}$ All national and international health advisories are busy suggesting measures to decrease the rates of caesarean section. ${ }^{3,4}$

The first step on which all have reached consensus is the need for audit of caesarean section rates so that the rates of caesarean section can be compared between different 
societies, institutions, and countries. This comparison will enable the experts to ponder on to which practices make the rate to differ and which areas need to be focused. One such method of audit on which there is almost universal agreement is Robson's ten group classification system (RTGC). ${ }^{5-7}$ RTGC or its some modification not only allows comparison between two centres at a point of time but also highlights the changing trends between specified time periods..$^{8-10}$

The next question is how easily this data is available from a maternity hospital. WHO gives an example where 200 cases out of 10608 deliveries that could not be classified in the Robson Classification. ${ }^{3}$ RTGC system means allotting the caesarean cases to the ten groups or to the subgroups of its modified form as per their clinical status at the time of caesarean section. ${ }^{11}$ For this either the operation theatre register (OT register) can be referred or the indoor papers of caesarean section from medical record section have to be referred. If the data is available from the OT register, it is the easiest and fastest method of allotting cases to the ten groups of RTGC or to its subgroups in modified system. But if OT register fails to provide the data, visiting medical record section becomes a necessity. Visiting medical record section means visiting dusty rooms, getting down hospital ward wise and month wise bundles of the cases papers, segregating caesarean section cases from it and then turning pages after pages to get the data. Often the case papers are missing for reasons like- mortality, transfer of case to other wards or papers issued temporarily to some other researcher. Often the documentation may be insufficient. ${ }^{12}$ Robson classification: implementation manual by WHO clearly mentions such missing information and suggests need of remedies to avoid this. ${ }^{4}$

The standard presently used formats of OT registers usually indicate the diagnosis of the disease condition and the indication for surgery. The indication usually written is such that it explains the need of surgery i.e. justifies the surgery done. Often in caesarean section 'obstructed labour', 'previous caesarean section', 'foetal distress, 'transverse lie', 'hand prolapse' are perceived as enough information required for OT register entry. These entries in OT registers however do not mention parity, gestation age, presentation, previous mode of delivery if any, the present status of labour activity which in fact are vital for RTGC. This information may be available from indoor case papers but is lost in record section and it is difficult and cumbersome if not impossible to recover it if the records are not digitized or computerized as is the case with most of the developing and underdeveloped countries.

We studied our OT registers to know if the information entered in it can provide data to allot consecutive 100 cases of caesarean sections to Ten Groups of Robson's classification. We also suggest an OT register format so that data on classification of caesarean sections can be easily and rapidly available from the OT registers for the purpose of audit.

\section{METHODS}

The first step in this study, of knowing adequacy of caesarean section OT registers in providing enough information to enable classification of caesarean sections into ten groups suggested by Michael Robson, was to coordinate with authors at other institution. The institution-1 is located at Nanded, Maharashtra and institution-2 at Adilabad, Telangana. We thought it appropriate to prefer an institution from adjoining state having different language and cultural practices but personally knowing the authors each other was of convenience to undertake the study. This was done to know the practice of caesarean section entry in OT registers there. In consultation with the co-authors a study master chart format was prepared which would accommodate all that information that is required for categorizing cases into Robson ten groups.

Table 1: Study master chart format for Robson ten group classification system for caesarean section audit: are our OT registers RTGC enabled.

\begin{tabular}{|c|c|c|c|c|c|c|c|c|c|c|}
\hline \multirow[b]{2}{*}{$\stackrel{\ominus}{\boxminus}$} & \multirow[b]{2}{*}{ 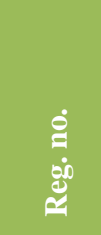 } & \multirow[b]{2}{*}{ 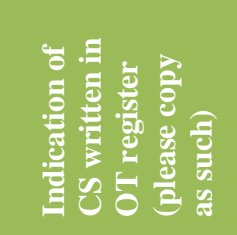 } & \multicolumn{8}{|c|}{ RTGC information evident from OT registers. } \\
\hline & & & 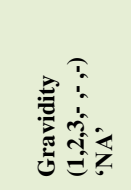 & 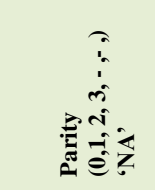 & 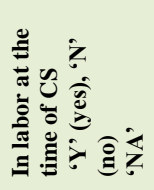 & 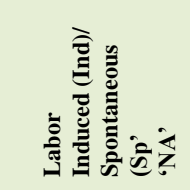 & 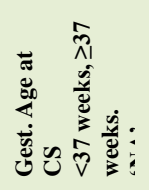 & 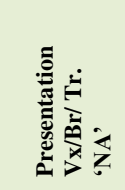 & 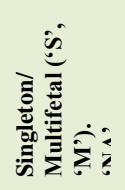 & 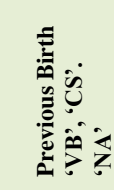 \\
\hline Ex: 1 & 00 & Prolonged labor & NA & NA & $\mathrm{Y}$ & NA & NA & NA & $\mathrm{S}$ & NA \\
\hline Ex: 2 & 000 & $\begin{array}{l}\text { Primi, Fetal } \\
\text { distress }\end{array}$ & 1 & 0 & NA & NA & NA & NA & NA & 0 \\
\hline Ex: 3 & 0000 & Prev CS & NA & NA & NA & NA & NA & NA & NA & CS \\
\hline Ex: 4 & 00000 & $\begin{array}{l}2^{\text {nd }} \text { gravida, } \\
\text { severe } \\
\text { oligohydramnios }\end{array}$ & 2 & NA & NA & NA & NA & NA & NA & NA \\
\hline
\end{tabular}


The master chart is as shown in Table 1. This chart was provided to both the institutions. The information was either available in the OT register, not available in the OT register or could be interpreted from the entries in columns assigned for diagnosis and indication for surgery. Consecutive 100 cases were taken from each centre. The information was entered into the study master chart (Table 1) and the percentage of cases where information is not available was known (Table 2). This was done with the purpose of designing an OT register format for caesarean section cases which would include all information required for RTGC system and add ease and perfection to the audit in future.

\section{RESULTS}

The annual births at Nanded centre are 10,089 and that at Adilabad are 6966. The total number of caesarean section in a year at Nanded centre were 2324 and at Adilabad 3002 . Thus $23 \%$ of births at Nanded were by caesarean section but at Adilabad centre $56 \%$ were delivered by caesarean section.

Table 2: Data missing cases on various variables required for RTGC system.

\begin{tabular}{|lll|}
\hline Factors/ variables necessary for RTGC system & $\begin{array}{l}\text { Percentage of cases data not } \\
\text { available Institution } \mathbf{1}(\mathbf{n}=\mathbf{1 0 0})\end{array}$ & $\begin{array}{l}\text { Percentage of cases data not } \\
\text { available Institution } \mathbf{2}(\mathbf{n}=\mathbf{1 0 0})\end{array}$ \\
\hline Parity & $0 \%$ & 3 \\
\hline Presentation and lie & $0 \%$ & 5 \\
\hline Gestational age & 2 & 45 \\
\hline Labour status: in labour or not in labour & 30 & 73 \\
\hline Labour: spontaneous or induced & 100 & 0 \\
\hline Singleton or multifetal & 0 & 3 \\
\hline Previous birth: caesarean or vaginal & 47 & 3 \\
\hline
\end{tabular}

Table 3: Columns that need to be incorporated in caesarean section OT register to enable it RTGC friendly.

\begin{tabular}{|c|c|c|c|c|c|c|c|}
\hline \multicolumn{8}{|c|}{ RTGC system information } \\
\hline $\begin{array}{l}\text { Gravidity } \\
(1,2,3,-,-)\end{array}$ & $\begin{array}{l}\text { Parity } \\
(0,1,2,3,-)\end{array}$ & $\begin{array}{l}\text { In labour at } \\
\text { the time of CS } \\
\text { (yes/ no) }\end{array}$ & $\begin{array}{l}\text { Labour } \\
\text { Induced (Ind) } \\
\text { Spontaneous (Spon) }\end{array}$ & $\begin{array}{l}\text { Gest. Age at CS } \\
<37 \text { weeks, } \geq 37 \\
\text { weeks. }\end{array}$ & $\begin{array}{l}\text { Presentation } \\
\mathrm{Vx} / \mathrm{Br} / \mathrm{Tr} \text {. }\end{array}$ & $\begin{array}{l}\text { Singleton/ } \\
\text { Multifetal } \\
\text { (Sf/ Mf). }\end{array}$ & $\begin{array}{l}\text { Previous } \\
\text { Birth } \\
\text { VB/ CS }\end{array}$ \\
\hline
\end{tabular}

Table 4: Rubber stamp that would help making existing OT registers RTGC friendly.

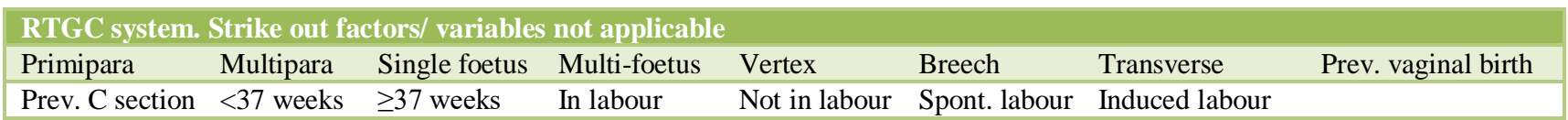

The information from both the institutions shows that data on many areas as regards RTGC system is missing from the traditional OT registers presently in use. Table 2 shows that in sizable number of cases data regarding labour status was neither available nor could be inferred (interpreted) from the entries made in OT register. At one centre in no case the information regarding labour whether spontaneous or induced was available, at other institution it was absent in $73 \%$ of cases. Similarly whether the women at the time of caesarean section were in labour or not was absent in $30 \%$ and $45 \%$ of cases. Labour status knowledge categorizes caesarean section cases to first four groups; its lack makes allotment of cases to first four groups just impossible.

\section{DISCUSSION}

RTGC system is seen as a saviour from the dreaded rise in caesarean section rates which has serious health and economic consequences. It allows us to know the groups that contributes maximum number cases to the total of caesarean sections and directs us to plan a strategy to reduce this contribution. In busy and under-resourced centres maintaining data and analysing it is often a difficult and low priority activity. Lack of enough manpower and non-computerization of data recording and storage makes it further difficult. Traditional system of OT register entries mention indication of caesarean section (foetal, maternal, feto-maternal) but fail to mention the status of woman as suggested by Robson. Analysing OT registers is relatively simple task when compared to analysing case papers from record sections.

Our analysis shows that in majority of cases the labour state of the woman at the time of caesarean section (in labour or not, labour induced or spontaneous) is not available at both the centres. This makes allotment of cases to the first four Robson groups just impossible. A study carried out in our region (Kishore B. Atnurkar, Arun R. Mahale) indicates that first four groups together 
contribute to $60 \%$ of cases of caesarean section. ${ }^{11}$ It means that for lack of this information contribution by these groups will be unknown and unaddressed. Looking at the caesarean section rates at these two centres, $23 \%$ and $56 \%$, it would be interesting to compare their RTGC audits after modifying the existing OT registers.

\section{CONCLUSION}

We conclude that the present OT registers are inadequate for RTGC system audit and therefore need modifications to make them RTGC enabled of RTGC friendly. These modifications would make caesarean section audit a perfect and easy task. We suggest that a column as shown in Table 3 should be incorporated into the caesarean section registers maintained at maternity hospitals. Till the time appropriate for printing and implementing new OT registers an impression of a rubber stamp as shown in Table 4 should be stamped in the remark column or some other column of OT register and utilized for entering RTGC related information. To conclude all maternity setups should assess their OT registers for adequacy of RTGC audit and modify it if needed.

Funding: No funding sources

Conflict of interest: None declared

Ethical approval: Not required

\section{REFERENCES}

1. Betrán AP, Ye J, Moller AB, Zhang J, Gülmezoglu AM, Torloni MR. The Increasing Trend in Caesarean Section Rates: Global, Regional and National Estimates: 1990-2014. PLoS ONE. 2016;11(2):e0148343.

2. Soha S, Arroyo-Manzano D, Murugesu N, Karthikeyan G, Kumar V. Maternal and perinatal mortality and complications associated with caesarean section in low-income and middle-income countries: a systematic review and meta-analysis. Lancet. 2019;393:1973-82.

3. World Health Organization; 2017. Robson Classification: Example of Robson Report Table with Interpretation. Geneva: Available at: WHO/RHR/17.22. https://www.who.int/iris/handle/10665/259513.

Accessed on $9^{\text {th }}$ July 2019.

4. World Health Organization, Geneva; 2017. Robson Classification: Implementation Manual. Available at: https://apps.who.int/iris/bitstream/10665/259512/1/9 789241513197-eng.pdf?ua=1. Accessed on $9^{\text {th }}$ July 2019.

5. Vogel JP, Betrán AP, Vindevoghel N, Souza JP, Torlonietal MR. Use of the Robson classification to assess caesarean sectiontrends in 21 countries: a secondary analysis of two WHO multicountry surveys. Lancet Glob Health 2015;3:e260-70.

6. Robson M. The Ten Group Classification System (TGCS) - a common starting point for more detailed analysis. Brit J Obstet Gynecol. 2015;122:701.

7. European board and college of obstetrics and gynaecology Ebcog. EBCOG position statement on caesarean section in Europe. Eur J Obstet Gynecol Reprod Biol. 2017;219:129.

8. Robson MS. Classification of caesarean sections. Fetal and Maternal Medicine Review. 2001;12(1):2339.

9. Robson MS, Scudamore IW, Walsh SM. Using the medical audit cycle to reduce caesarean section rates. Am J ObstetGynecol. 1996;174(1):199-205.

10. Farine D, Shephard D. Classification of caesarean sections in Canada: the modified Robson criteria. J Obstet Gynaecol Can. 2012;34(10):976-83.

11. Atnurkar KB, Mahale AR. Audit of caesarean section births in small private maternity homes: analysis of 15-year data applying the modified Robson criteria, Canada. J Obstet Gynecol India. 2016;66(S1):S289-94.

12. FadlElmula ZS, Bolad AK. Standard documentation of paper-based medical records at four main hospitals in Khartoum state, Sudan, 2014-2015. AlbasarInt J Ophthalmol. 2017;4:75-8.

Cite this article as: Aziz FTA, Bhoosreddy SR. Robson ten groups classification (RTGC) system for caesarean section audit: are our operation theatre registers RTGC enabled?. Int J Reprod Contracept Obstet Gynecol 2019;8:3675-8. 